\title{
Effect of high-sugar grasses on methane emissions simulated using a dynamic model
}

\author{
J. L. Ellis, ${ }^{*}{ }^{1}$ J. Dijkstra, $†$ J. France, ${ }^{\star}$ A. J. Parsons,‡ G. R. Edwards,§ S. Rasmussen,‡ E. Kebreab,\# \\ and A. Banninkll \\ ${ }^{*}$ Centre for Nutrition Modelling, Department of Animal and Poultry Science, University of Guelph, Guelph, ON, N1G 2W1 Canada \\ †Animal Nutrition Group, Wageningen University, 6708 WD Wageningen, the Netherlands \\ $\ddagger$ AgResearch, Palmerston North 4442, New Zealand \\ $\S$ Lincoln University, Lincoln 7647, New Zealand \\ \#Department of Animal Science, University of California, Davis 95616 \\ II Wageningen University and Research Centre (UR) Livestock Research, 8219 PH Lelystad, the Netherlands
}

\begin{abstract}
High-sugar grass varieties have received considerable attention for their potential ability to decrease $\mathrm{N}$ excretion in cattle. However, feeding high-sugar grasses alters the pattern of rumen fermentation, and no in vivo studies to date have examined this strategy with respect to another environmental pollutant: methane $\left(\mathrm{CH}_{4}\right)$. Modeling allows us to examine potential outcomes of feeding strategies under controlled conditions, and can provide a useful framework for the development of future experiments. The purpose of the present study was to use a modeling approach to evaluate the effect of high-sugar grasses on simulated $\mathrm{CH}_{4}$ emissions in dairy cattle. An extant dynamic, mechanistic model of enteric fermentation and intestinal digestion was used for this evaluation. A simulation database was constructed and analysis of model behavior was undertaken to simulate the effect of (1) level of water-soluble carbohydrate (WSC) increase in dietary dry matter, (2) change in crude protein $(\mathrm{CP})$ and neutral detergent fiber (NDF) content of the plant with an increased WSC content, (3) level of $\mathrm{N}$ fertilization, and (4) presence or absence of grain feeding. Simulated $\mathrm{CH}_{4}$ emissions tended to increase with increased WSC content when $\mathrm{CH}_{4}$ was expressed as megajoules per day or percent of gross energy intake, but when $\mathrm{CH}_{4}$ was expressed in terms of grams per kilogram of milk, results were much more variable due to the potential increase in milk yield. As a result, under certain conditions, $\mathrm{CH}_{4}$ (g/ $\mathrm{kg}$ of milk) decreased. The largest increases in $\mathrm{CH}_{4}$ emissions $(\mathrm{MJ} / \mathrm{d}$ or \% gross energy intake) were generally seen when WSC increased at the expense of CP in the diet and this can largely be explained by the representation in the model of the type of volatile fatty acid produced.
\end{abstract}

Received March 23, 2011.

Accepted September 10, 2011

${ }^{1}$ Corresponding author: jellis@uoguelph.ca
Effects were lower when WSC increased at the expense of NDF, and intermediary when WSC increased at the expense of a mixture of $\mathrm{CP}$ and NDF. When WSC increased at the expense of NDF, simulated milk yield increased and, therefore, $\mathrm{CH}_{4}(\mathrm{~g} / \mathrm{kg}$ of milk) tended to decrease. Diminished increases of $\mathrm{CH}_{4}$ (\% gross energy intake or $\mathrm{g} / \mathrm{kg}$ of milk) were simulated when DMI was increased with elevated WSC content. Simulation results suggest that high WSC grass, as a strategy to mitigate $\mathrm{N}$ emission, may increase $\mathrm{CH}_{4}$ emissions, but that results depend on the grass composition, DMI, and the units chosen to express $\mathrm{CH}_{4}$. Overall, this project demonstrates the usefulness of modeling for hypothesis testing in the absence of observed experimental results. Key words: high-sugar grass, methane, modeling

\section{INTRODUCTION}

Feeding high water-soluble carbohydrate (WSC) grass varieties is proposed as a means to decrease $\mathrm{N}$ excretion in urine and feces, and lessen the environmental impact of grazing cattle. The concept is that high amounts of readily available energy from high-WSC grasses support the microbial capture of degraded grass protein. When the supply of carbon to the rumen is inadequate, the excess protein not incorporated into microbial protein is degraded to ammonia and subsequently excreted as urea in the urine. Thus, increasing the sugar content of grasses could rectify the imbalance of carbon and $\mathrm{N}$ being delivered to the rumen microbes, thereby making $\mathrm{N}$ utilization by the microbes more efficient and decreasing $\mathrm{N}$ loss from the animal (Miller et al., 2001a,b).

Edwards et al. (2007) produced a comprehensive review of the trials done to date by the 3 main groups that have been participating in sugar grass research: the UK studies (Miller et al., 2000, 2001a,b; Moorby et al., 2006), the Dutch studies (Tas et al., 2005; 2006a,b; Taweel et al., 2005a,b, 2006), and the Australian and 
New Zealand studies (Cosgrove et al., 2007). However, substantial between-study variation was evident. As a result, Ellis et al. (2011) conducted a systematic evaluation of the literature and performed model simulations for high-WSC grass data considering (1) the level of $\mathrm{g}$ of WSC $/ \mathrm{kg}$ of DM increase over the control grass, (2) where the increase of WSC occurred at the expense of $\mathrm{CP}$ or NDF, (3) grass $\mathrm{N}$ fertilization level, and (4) the presence or absence of grain feeding. This type of analysis (Ellis et al., 2011) provides a valuable framework of expected results given variable grass composition scenarios.

The main interest of the current paper lies with another environmental pollutant: methane $\left(\mathrm{CH}_{4}\right)$. Methane is produced by ruminants as the result of microbial fermentation; it represents an energy loss to the animal, and it is also a potent greenhouse gas. For dairy cattle, $\mathrm{CH}_{4}$ is the largest on-farm contributor to the greenhouse gas effect and global warming (for a recent review, see Beauchemin et al., 2009). Methane emissions from high-WSC grass-fed cattle have not been measured simultaneously with $\mathrm{N}$ excretion in any in vivo peer reviewed study to date. As $\mathrm{CH}_{4}$ is produced predominantly by the microbes in the rumen, a change in feeding strategy that alters rumen fermentation and decreases $\mathrm{N}$ loss may also alter $\mathrm{CH}_{4}$ production by the animal (for a review, see Ellis et al., 2008). Dijkstra et al. (2007) examined challenges to predicting the profile of nutrients available for absorption in dairy cattle, in view of mitigation options of various pollutants. The authors suggested that management strategies that adjust feed composition and characteristics have a large effect on simulated total $\mathrm{N}$ and $\mathrm{CH}_{4}$ emissions. Subsequently, Ellis et al. (2009) suggested that feeding highWSC grasses as an $\mathrm{N}$ mitigation strategy can increase $\mathrm{CH}_{4}$ emissions when no change in DMI is simulated. Recently, Gregorini et al. (2010), using a whole-farm modeling approach, outlined an evaluation of some feeding strategies on $\mathrm{N}$ excretion and $\mathrm{CH}_{4}$ emission from grazing cattle, including high-WSC grasses. Initial results also suggested that feeding strategies to decrease urinary $\mathrm{N}$ excretion may increase $\mathrm{CH}_{4}$ emissions.

As no peer-reviewed studies currently exist to examine the underlying relationship between high-WSC grasses, observed $\mathrm{CH}_{4}$ emissions, and observed $\mathrm{N}$ excretion, the aim of this study was to understand and quantify this relationship using a modeling approach, in greater detail than Gregorini et al. (2010), who adopted a whole-farm approach without describing the underlying mechanisms. The effects of feeding high-WSC grasses on $\mathrm{CH}_{4}$ emissions, using the high-WSC grass simulation scenarios and database previously evaluated by Ellis et al. (2011) for N excretion, are simulated.

\section{MATERIALS AND METHODS}

\section{Model}

The same model used by Ellis et al. (2011) to evaluate $\mathrm{N}$ and milk yield predictions with high-WSC grass feeding was applied here to evaluate simulated $\mathrm{CH}_{4}$ emissions. In summary, an adapted version of the rumen model of Dijkstra et al. (1992) was used that simulates the digestion, absorption, and outflow of nutrients in the rumen and hindgut. Modifications to the original model of Dijkstra et al. (1992) include an updated pH-dependent VFA stoichiometry from Bannink et al. (2008), a hydrogen balance submodel and hindgut fermentation model developed by Mills et al. (2001), calculations for N excretion developed by Reijs (2007), and ruminal fractional passage rate equations developed by Seo et al. (2006).

Methane. Mills et al. (2001) expanded the rumen model of Dijkstra et al. (1992) to include a hydrogen balance submodel within the rumen and to represent hindgut fermentation. The rumen hydrogen balance submodel is a development of the hydrogen model of Baldwin et al. (1987a,b,c), used for evaluation in Benchaar et al. (1998). In the Mills et al. (2001) model, from the hydrogen balance submodel for the rumen and hindgut, total enteric $\mathrm{CH}_{4}$ production is calculated. A schematic representation of the $\mathrm{CH}_{4}$ emission part of the model is shown in Figure 1, and inputs to the $\mathrm{H}_{2}$ submodel include (1) $\mathrm{H}_{2}$ produced with acetate and butyrate (lipogenic VFA) during fermentation of carbohydrates and protein, and (2) $\mathrm{H}_{2}$ produced as microbial populations utilized AA for growth. Outputs of the model included (1) utilization of $\mathrm{H}_{2}$ with propionate and valerate as end products of fermentation of carbohydrates and protein (glucogenic VFA), (2) utilization of $\mathrm{H}_{2}$ for growth of microbial populations on ammonia$\mathrm{N}$, and (3) the utilization of $\mathrm{H}_{2}$ for biohydrogenation of ingested lipids. In this model, hydrogen gas $\left(\mathrm{H}_{\mathrm{y}}\right)$ is represented as a zero pool, meaning that net surplus of $\mathrm{H}_{2}\left(\mathrm{H}_{2}\right.$ produced minus $\mathrm{H}_{2}$ utilized $)$ is completely utilized for $\mathrm{CH}_{4}$ production by methanogens. Methane production is, hence, estimated from the $\mathrm{H}_{2}$ balance as $\mathrm{CH}_{4}(\mathrm{MJ} / \mathrm{d})=\left(\mathrm{H}_{\mathrm{y}} / 4\right) \times 0.883$, which assumes that 4 mol of $\mathrm{H}_{2}$ is required to produce $1 \mathrm{~mol}$ of $\mathrm{CH}_{4}$ and 0.883 is the heat of combustion of $\mathrm{CH}_{4}$ in $\mathrm{MJ} / \mathrm{mol}$ (Benchaar et al., 1998).

Milk Yield. Milk yield was simulated as in Ellis et al. (2011). Briefly, absorbed nutrients from the diet were defined as glucogenic nutrients, lipogenic nutrients, and aminogenic nutrients. The model calculates the amount of energy available for absorption from these nutrients and their respective energy contents. Milk yield is determined by the most limiting supply 


$\begin{array}{cc}\begin{array}{c}\text { H produced with } \\ \text { fermentation of } \\ \text { carbohydrate and } \\ \text { protein to acetate and } \\ \text { butyrate }(\mathrm{mol} / \mathrm{d})\end{array} & \begin{array}{c}\mathrm{H} \text { produced as } \\ \text { microbes utilize }\end{array} \\ \text { amino acids for } \\ \text { growth }(\mathrm{mol} / \mathrm{d})\end{array}$

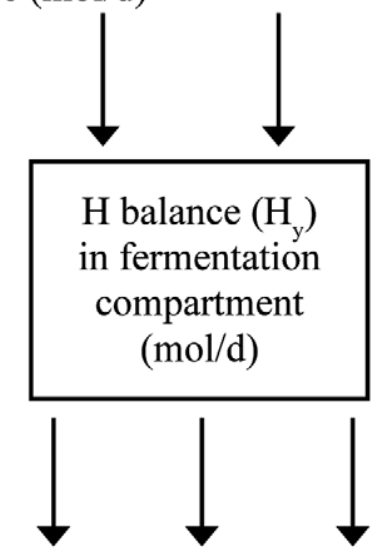

\section{$\mathrm{H}$ utilized with fermentation of carbohydrate and protein to propionate and valerate $(\mathrm{mol} / \mathrm{d})$}

Figure 1. Hydrogen gas $\left(\mathrm{H}_{\mathrm{y}}\right)$ balance model described by Mills et al. (2001) and incorporated into an adapted and extended version of the Dijkstra et al. (1992) rumen model. Methane production is estimated from $\mathrm{H}_{\mathrm{y}}$ as $\mathrm{CH}_{4}(\mathrm{MJ} / \mathrm{d})=\left(\mathrm{H}_{\mathrm{y}} / 4\right) \times 0.883$, which assumes that $4 \mathrm{~mol}$ of $\mathrm{H}_{\mathrm{y}}$ are required to produce $1 \mathrm{~mol}$ of $\mathrm{CH}_{4}$, and 0.883 is the heat combustion of $\mathrm{CH}_{4}$ in $\mathrm{MJ} / \mathrm{mol}$.

among glucogenic nutrients, aminogenic nutrients, lipogenic nutrients, and energy (Dijkstra et al., 1996). If the supply of glucogenic nutrients is first limiting, aminogenic nutrients that are in excess may be used for gluconeogenesis, assuming $0.6 \mathrm{~g} / \mathrm{g}$ of the absorbed AA to be glucogenic (Dijkstra et al., 2008).

Fat- and protein-corrected milk yield $(3.5 \%$ fat and $3.2 \%$ protein; $\mathrm{kg} / \mathrm{d})$ was calculated as $0.3246 \times$ milk yield $(\mathrm{kg} / \mathrm{d})+12.86 \times$ milk fat $(\mathrm{kg} / \mathrm{d})+7.04 \times$ milk protein $(\mathrm{kg} / \mathrm{d}$; Bernard, 1997). All references in the present study to milk yield are fat- and proteincorrected values.

\section{Simulation Scenarios}

To evaluate the behavior of the model given a wide variety of high-WSC grass compositions and feeding scenarios, the following simulations, identical to the simulations performed in Ellis et al. (2011), were undertaken. High-WSC grass simulations are presented in Table 1 and represent inputs for the above-described

mechanistic model. The WSC fraction of grass $(\mathrm{g} / \mathrm{kg}$ of DM) was increased by 3 levels: 20, 60, and $90 \mathrm{~g} / \mathrm{kg}$ of $\mathrm{DM}$ at the expense of CP, NDF, or a 50:50 split of CP and NDF. Two N levels of the grass were simulated, representing normal and high-N fertilization levels. Dry matter intake was increased by $0.3 \mathrm{~kg} / \mathrm{d}$ with the high$\mathrm{N}$ fertilized grass, to represent the observed relationship between N fertilization of grass and DMI (Valk et al., 2000). Simulations were performed on $100 \%$ grass diets, and again with the addition of $2 \mathrm{~kg}$ of concentrate/d, resulting in an $89 \%$ grass diet, on average. Chemical composition of feed ingredients was derived from feeding tables (Sauvant et al., 2004; CVB, 2007).

Assumptions on BW, DMI, milk composition and degradation characteristics of $\mathrm{CP}$ and NDF fractions of grass are as per Ellis et al. (2011). Cows had a BW of $596 \mathrm{~kg}$, DMI was in the range of 16.0 to $18.3 \mathrm{~kg} / \mathrm{d}$ (see Table 1 for details), and milk contained $4.21 \%$ fat, $3.31 \%$ protein, and $4.53 \%$ lactose. Degradation characteristics of the NDF and CP content of grasses were determined by regression analysis of the data of Valk et al. (1996), and are presented in Ellis et al. (2011).

\section{RESULTS AND DISCUSSION}

\section{Simulation Scenarios}

This study posed the question: what level of $\mathrm{CH}_{4}$ emissions would be achieved under the high-WSC grass feeding strategy? Much credit has been given to highWSC grasses as an N mitigation strategy, even though results in the literature appear inconsistent (e.g., see Edwards et al., 2007). Our previous paper (Ellis et al., 2011) demonstrated that variation in $\mathrm{N}$ excretion and milk yield responses could be attributed to simultaneous changes in the grass composition and diet fed. It is likely that effects of high-WSC grass on $\mathrm{CH}_{4}$ emissions are just as variable as their effects on $\mathrm{N}$ emissions.

Systematic evaluation of individual grass composition scenarios in terms of $\mathrm{N}$ and milk yield revealed in Ellis et al. (2011) an underlying pattern, though it is not initially evident in meta-analysis. Interfering factors are diet digestibility; actual increase in WSC (g/ $\mathrm{kg}$ of DM) achieved; whether that increase is at the expense of $\mathrm{CP}, \mathrm{NDF}$, or a combination of the 2 ; and underlying factors such as rumen $\mathrm{pH}$ and passage rate, as influenced by animal characteristics such as BW and gut volume. Additional factors may be the basal level of $\mathrm{N}$ fertilization adopted in trials and the presence or absence of grain feeding.

Results of $\mathrm{CH}_{4}$ predictions according to the simulations described in Table 1 are presented in Tables 2 and 3. Results suggest that the effect of high-WSC grass feeding on simulated $\mathrm{CH}_{4}$ emissions depend on both the 
Table 1. Summary of simulations conducted

\begin{tabular}{|c|c|c|c|c|c|c|}
\hline $\begin{array}{l}\text { Simulation } \\
\text { identification }^{1}\end{array}$ & Description $^{2}$ & $\begin{array}{l}\text { Grass WSC } \\
(\mathrm{g} / \mathrm{kg} \text { of } \mathrm{DM})\end{array}$ & $\begin{array}{c}\text { Grass CP } \\
(\mathrm{g} / \mathrm{kg} \text { of } \mathrm{DM})\end{array}$ & $\begin{array}{c}\text { Grass NDF } \\
(\mathrm{g} / \mathrm{kg} \text { of } \mathrm{DM})\end{array}$ & WSC: $\mathrm{CP}^{3}$ & $\begin{array}{l}\mathrm{DMI}^{4} \\
(\mathrm{~kg} / \mathrm{d})\end{array}$ \\
\hline 1,21 & $\mathrm{LN} / \mathrm{B} / 0, \mathrm{G}$ & 171 & 200 & 501 & $0.86,0.81$ & $16.0,18.0$ \\
\hline 2,22 & $\mathrm{LN} / \mathrm{CP} / 20, \mathrm{G}$ & 191 & 180 & 501 & $1.06,0.98$ & $16.0,18.0$ \\
\hline 3,23 & $\mathrm{LN} / \mathrm{CP} / 60, \mathrm{G}$ & 231 & 140 & 501 & $1.65,1.45$ & $16.0,18.0$ \\
\hline 4,24 & $\mathrm{LN} / \mathrm{CP} / 90, \mathrm{G}$ & 261 & 110 & 501 & $2.37,1.99$ & $16.0,18.0$ \\
\hline 5,25 & $\mathrm{LN} / \mathrm{NDF} / 20, \mathrm{G}$ & 191 & 200 & 481 & $0.96,0.90$ & $16.0,18.0$ \\
\hline 6,26 & $\mathrm{LN}^{\prime} / \mathrm{NDF} / 60, \mathrm{G}$ & 231 & 200 & 441 & $1.16,1.07$ & $16.0,18.0$ \\
\hline 7,27 & $\mathrm{LN} / \mathrm{NDF} / 90, \mathrm{G}$ & 261 & 200 & 411 & $1.31,1.20$ & $16.0,18.0$ \\
\hline 8,28 & $\mathrm{LN} / \mathrm{CN} / 20, \mathrm{G}$ & 191 & 190 & 491 & $1.01,0.94$ & $16.0,18.0$ \\
\hline 9,29 & $\mathrm{LN} / \mathrm{CN} / 60, \mathrm{G}$ & 231 & 170 & 471 & $1.36,1.23$ & $16.0,18.0$ \\
\hline 10,30 & $\mathrm{LN} / \mathrm{CN} / 90, \mathrm{G}$ & 261 & 155 & 456 & $1.68,1.50$ & $16.0,18.0$ \\
\hline 11,31 & $\mathrm{HN} / \mathrm{B} / 0, \mathrm{G}$ & 121 & 250 & 501 & $0.48,0.48$ & $16.3,18.3$ \\
\hline 12,32 & $\mathrm{HN} / \mathrm{CP} / 20, \mathrm{G}$ & 141 & 230 & 501 & $0.61,0.60$ & $16.3,18.3$ \\
\hline 13,33 & $\mathrm{HN} / \mathrm{CP} / 60, \mathrm{G}$ & 181 & 190 & 501 & $0.95,0.89$ & $16.3,18.3$ \\
\hline 14,34 & $\mathrm{HN} / \mathrm{CP} / 90, \mathrm{G}$ & 211 & 160 & 501 & $1.32,1.20$ & $16.3,18.3$ \\
\hline 15,35 & $\mathrm{HN} / \mathrm{NDF} / 20, \mathrm{G}$ & 141 & 250 & 481 & $0.56,0.55$ & $16.3,18.3$ \\
\hline 16,36 & $\mathrm{HN} / \mathrm{NDF} / 60, \mathrm{G}$ & 181 & 250 & 441 & $0.72,0.70$ & $16.3,18.3$ \\
\hline 17,37 & $\mathrm{HN} / \mathrm{NDF} / 90, \mathrm{G}$ & 211 & 250 & 411 & $0.84,0.81$ & $16.3,18.3$ \\
\hline 18,38 & $\mathrm{HN} / \mathrm{CN} / 20, \mathrm{G}$ & 141 & 240 & 491 & $0.59,0.58$ & $16.3,18.3$ \\
\hline 19,39 & $\mathrm{HN} / \mathrm{CN} / 60, \mathrm{G}$ & 181 & 220 & 471 & $0.82,0.78$ & $16.3,18.3$ \\
\hline 20,40 & $\mathrm{HN} / \mathrm{CN} / 90, \mathrm{G}$ & 211 & 205 & 456 & $1.03,0.96$ & $16.3,18.3$ \\
\hline
\end{tabular}

${ }^{1}$ Simulations 1 to 20 are $100 \%$ grass diets with DMI of 16.0 or $16.3 \mathrm{~kg}$ of DM/d, respectively; simulations 21 to 40 are using the same grass as diets 1 to 20 , but have an additional $2 \mathrm{~kg}$ of concentrate DM fed per day [concentrate composition (g/kg of DM): 195 wheat, 150 soybean meal, 150 sugar beet pulp, 130 palm kernel meal, 110 rapeseed meal, 90 maize gluten, 80 molasses, 70 sunflower meal, 10 vegetable oil, and 10 trace mineral mixture; $\mathrm{CP}=225, \mathrm{NDF}=336$, fat $=41$, water-soluble carbohydrates $(\mathrm{WSC})=107$, starch $=222$, and ash $=69]$.

${ }^{2}$ Simulations 1 to 10 and 21 to 30 represent low-N fertilized grass (LN), and simulations 11 to 20 and 31 to 40 represent high-N fertilized grass (HN); basal WSC levels are represented by B, and WSC increases at the expense of $\mathrm{CP}, \mathrm{NDF}$, or a 50:50 split of $\mathrm{CP}$ and $\mathrm{NDF}(\mathrm{CN}) ; 20,60$, and 90 represent the level of grams per kilogram of DM trade with WSC as WSC of the grass increases; grain $(\mathrm{G})$ is fed in simulations 21 to 40.

${ }^{3}$ The WSC:CP ratio of the whole diet corresponds to simulation identification information in footnotes 1 and 2 .

${ }^{4}$ Corresponds to simulation identification information in footnotes 1 and 2 .

composition of the grass and diet, as well as the units that $\mathrm{CH}_{4}$ is expressed in. Regardless of grass composition, $\mathrm{N}$ fertilization level or presence or absence of grain feeding, simulated $\mathrm{CH}_{4}(\mathrm{MJ} / \mathrm{d})$ increased slightly as the WSC content of grass increased, by an average of $1.32 \mathrm{MJ} / \mathrm{d}$ or $4.6 \%$ across all simulations. Similarly, simulated $\mathrm{CH}_{4}$ [\% of gross energy intake (GEI)] increased as the WSC content of grass increased, by an average of $0.39 \mathrm{CH}_{4}$ (\% of GEI units) or $6.5 \%$ across all simulations. However, when $\mathrm{CH}_{4}$ was expressed as $\mathrm{g} / \mathrm{kg}$ of milk (fat and protein corrected), $\mathrm{CH}_{4}$ increased in most simulations but decreased in others. For all of the grass composition scenarios simulated, according to the model, energy was simulated to be the limiting factor for milk production, and therefore, the increase or decrease in simulated milk yield was partially contributed to by the change in NDF and CP digestibility of the diet.

WSC Increases at the Expense of CP. When WSC was increased in grass at the expense of CP (indicated from here on by "CP scenario"), simulated $\mathrm{CH}_{4}$ increased, regardless of the units (MJ/d, \% of GEI, or $\mathrm{g} / \mathrm{kg}$ of milk; Tables 2 and 3 ). This increase occurred despite a decrease in simulated NDF and CP digestibility (results presented in Ellis et al., 2011). The increase in $\mathrm{CH}_{4}$ under this scenario is at least partially the result of the pH-dependent VFA stoichiometry of the model, which states that relative $\mathrm{CH}_{4}$ formation is always higher with fermented WSC than fermented $\mathrm{CP}$, regardless of $\mathrm{pH}$ (Bannink et al., 2010). Methane formation with starch, NDF, and CP relative to WSC for high-forage diets within the stoichiometry of the model is illustrated visually in Figure 2.

Simulated $\mathrm{CH}_{4}$ results are qualitatively in agreement with the experimental results of Murray et al. (2001), who measured lower $\mathrm{CH}_{4}$ emissions (expressed in $\mathrm{g}$ of $\mathrm{CH}_{4} / \mathrm{kg}$ of DMI per kilogram of $\mathrm{BW}$ ) from grazing sheep on pasture with a higher level of $\mathrm{N}$ fertilization. As grass $\mathrm{CP}$ levels increase due to, for example, $\mathrm{N}$ fertilization, the WSC content decreases - a physiological plant phenomenon demonstrated by Valk et al. (1996). Essentially, a lower $\mathrm{N}$ fertilization level will slow plant growth rate, relative to the rate of photosynthesis. Thus, (temporarily) WSC accumulates in the plant. Slower growth also leads to a more mature plant at harvest time if harvest is postponed to compensate, which results in less CP and a larger (more lignified) cell wall fraction. Thus, NDF digestibility decreases, which was 
Table 2. Simulated methane emissions and milk yield without grain feeding

\begin{tabular}{|c|c|c|c|c|c|}
\hline $\begin{array}{l}\text { Simulation } \\
\text { identification }\end{array}$ & Description $^{1}$ & $\begin{array}{c}\mathrm{CH}_{4} \\
(\mathrm{MJ} / \mathrm{d})\end{array}$ & (\% of $\mathrm{GEI}^{2}$ ) & $\begin{array}{c}\mathrm{CH}_{4}(\mathrm{~g} / \mathrm{kg} \\
\left.\text { of } \text { milk }^{3}\right)\end{array}$ & $\begin{array}{l}\text { Milk yield }^{3} \\
\quad(\mathrm{~kg} / \mathrm{d})\end{array}$ \\
\hline 1 & $\mathrm{LN} / \mathrm{B}$ & 18.1 & 6.28 & 15.5 & 20.9 \\
\hline 2 & $\mathrm{LN} / \mathrm{CP} / 20$ & 18.3 & 6.43 & 16.0 & 20.7 \\
\hline 3 & $\mathrm{LN} / \mathrm{CP} / 60$ & 18.9 & 6.73 & 16.8 & 20.2 \\
\hline 4 & $\mathrm{LN} / \mathrm{CP} / 90$ & 19.3 & 6.98 & 17.4 & 19.9 \\
\hline 5 & $\mathrm{LN} / \mathrm{NDF} / 20$ & 18.4 & 6.44 & 15.5 & 21.4 \\
\hline 6 & $\mathrm{LN}^{\prime} \mathrm{NDF} / 60$ & 19.1 & 6.72 & 15.3 & 22.4 \\
\hline 7 & $\mathrm{LN} / \mathrm{NDF} / 90$ & 19.5 & 6.91 & 15.2 & 23.0 \\
\hline 8 & $\mathrm{LN} / \mathrm{CN} / 20$ & 18.4 & 6.43 & 15.7 & 21.0 \\
\hline 9 & $\mathrm{LN} / \mathrm{CN} / 60$ & 19.0 & 6.73 & 16.0 & 21.3 \\
\hline 10 & $\mathrm{LN} / \mathrm{CN} / 90$ & 19.4 & 6.95 & 16.3 & 21.5 \\
\hline 11 & $\mathrm{HN} / \mathrm{B}$ & 17.6 & 5.88 & 14.3 & 22.2 \\
\hline 12 & $\mathrm{HN} / \mathrm{CP} / 20$ & 17.9 & 6.02 & 14.7 & 21.9 \\
\hline 13 & $\mathrm{HN} / \mathrm{CP} / 60$ & 18.5 & 6.32 & 15.5 & 21.4 \\
\hline 14 & $\mathrm{HN} / \mathrm{CP} / 90$ & 18.9 & 6.55 & 16.2 & 21.0 \\
\hline 15 & $\mathrm{HN} / \mathrm{NDF} / 20$ & 18.0 & 6.04 & 14.2 & 22.7 \\
\hline 16 & $\mathrm{HN} / \mathrm{NDF} / 60$ & 18.6 & 6.31 & 14.1 & 23.7 \\
\hline 17 & $\mathrm{HN} / \mathrm{NDF} / 90$ & 19.1 & 6.50 & 14.0 & 24.4 \\
\hline 18 & $\mathrm{HN} / \mathrm{CN} / 20$ & 17.9 & 6.03 & 14.5 & 22.3 \\
\hline 19 & $\mathrm{HN} / \mathrm{CN} / 60$ & 18.6 & 6.33 & 14.8 & 22.5 \\
\hline 20 & $\mathrm{HN} / \mathrm{CN} / 90$ & 19.0 & 6.55 & 15.1 & 22.7 \\
\hline
\end{tabular}

${ }^{1} \mathrm{LN}$ represents low-N fertilized grass; HN represents high-N fertilized grass; basal water-soluble carbohydrate (WSC) levels are represented by B, and WSC increases at the expense of CP, NDF, or a 50:50 split of CP and NDF (CN); 20, 60, and 90 represent the level of grams per kilogram of DM trade that CP, NDF, or CN make with WSC as WSC of the grass increases.

${ }^{2} \mathrm{GEI}=$ gross energy intake.

${ }^{3}$ Milk yield is corrected to $3.5 \%$ milk fat and $3.2 \%$ milk protein.

also simulated in the present study. Observed $\mathrm{CH}_{4}$ emissions in the study of Murray et al. (2001) were 4.5 $\mathrm{g} / \mathrm{kg}$ of DM for the high-N fertilization level treatment, and significantly higher at $6.3 \mathrm{~g} / \mathrm{kg}$ of DM for the low$\mathrm{N}$ fertilization level treatment. These results support the VFA stoichiometry adopted in the present study (Bannink et al., 2008, 2010), which predicts less $\mathrm{CH}_{4}$ from fermented CP than from WSC.

Lovett et al. (2004) examined the effect of $\mathrm{N}$ application rate, regrowth number, and grass cultivar on in vitro $\mathrm{CH}_{4}(\mathrm{~mL} / \mathrm{g}$ of $\mathrm{OM})$ production levels. When $\mathrm{N}$ application rate increased from 0 to $160 \mathrm{~kg}$ of $\mathrm{N} / \mathrm{ha}$, the WSC content of grass decreased by $83 \mathrm{~g} / \mathrm{kg}$ of DM, whereas $\mathrm{CP}$ content increased. At $24 \mathrm{~h}, \mathrm{CH}_{4}(\mathrm{~mL} / \mathrm{g}$ of $\mathrm{OM}$ ) increased significantly with decreased $\mathrm{N}$ application rate and, hence, increased WSC content, and $\mathrm{CH}_{4}$ $(\mathrm{mL} / \mathrm{g}$ of digested $\mathrm{OM})$ numerically increased, which is in agreement with the predictions made here. However, in the Lovett et al. (2004) study, digestibility of OM also increased significantly, and this is in contrast with the simulated decrease in NDF and CP digestibility results for this scenario reported in Ellis et al. (2011).

WSC Increases at the Expense of NDF. When WSC increased at the expense of NDF in grass (indicated from here on by "NDF scenario"), simulated $\mathrm{CH}_{4}$ increased when expressed as megajoules per day or as a percentage of GEI, but decreased slightly when expressed as grams per kilogram of milk (Tables 2 and
3). Simulated $\mathrm{CH}_{4}$ in this dietary scenario increased slightly more compared with when WSC increased at the expense of $\mathrm{CP}$ (expressed as $\mathrm{MJ} / \mathrm{d}$ ). However, the increase was slightly less than for the CP scenario when $\mathrm{CH}_{4}$ was expressed as a percentage of GEI. In this scenario, NDF and CP digestibility increased slightly (Ellis et al., 2011) and likely contributed to the increase in simulated $\mathrm{CH}_{4}$ emissions over the former $\mathrm{CP}$ scenario.

Under the NDF scenario, it is likely that simulated $\mathrm{CH}_{4}$ will increase, based on the model of VFA stoichiometry. The VFA stoichiometry of the model predicts that fermented NDF will yield less $\mathrm{CH}_{4}$ than WSC, regardless of rumen $\mathrm{pH}$ (Figure 2). Based on the VFA stoichiometry alone, for the $\mathrm{pH}$ values simulated by the model $(\mathrm{pH}=5.9-6.0$; presented in Ellis et al. 2011), the trade of NDF for WSC in grass would, therefore, result in a larger amount of $\mathrm{CH}_{4}$ produced per unit of fermented substrate. However, the model also predicts an increase in NDF digestibility, which increases the amount of fermented NDF, and subsequently, the amount of $\mathrm{CH}_{4}$. Thus, whether observations of $\mathrm{CH}_{4}$ increase or stay the same under this dietary scenario may depend on grass digestibility as well as effects on ruminal $\mathrm{pH}$ and related stoichiometry of VFA production.

When Lovett et al. (2004) examined 2 grass cultivars differing in WSC content by $11 \mathrm{~g} / \mathrm{kg}$ of $\mathrm{DM}$, at the expense of $\mathrm{NDF}$, in vitro-measured $\mathrm{CH}_{4}(\mathrm{~mL} / \mathrm{g}$ of $\mathrm{OM})$ 


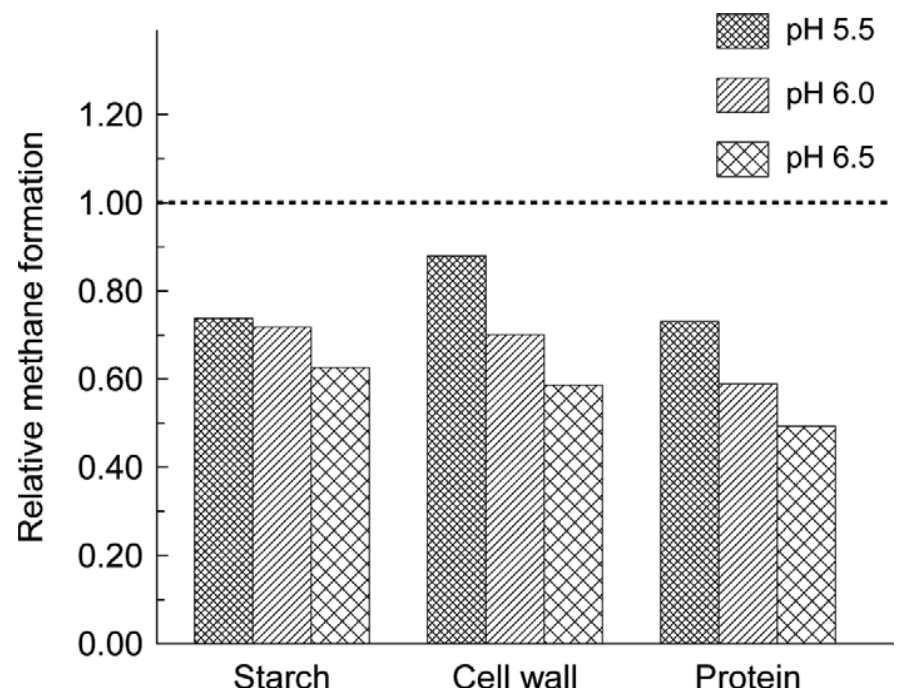

Figure 2. The methane formation of starch, cell wall carbohydrates, and protein ( $\mathrm{g}$ of $\mathrm{CH}_{4} / \mathrm{g}$ of substrate fermented into VFA) relative to that of sugars at different $\mathrm{pH}$ values on high-roughage diets. A value of 1.00 indicates $\mathrm{CH}_{4}$ formation of substrate is equal to that of sugars. Adapted from Bannink et al. (2010).

increased numerically but nonsignificantly. Methane $(\mathrm{mL} / \mathrm{g}$ of digested $\mathrm{OM})$ also increased numerically. Lovett et al. (2004) reported no significant difference in OM digestibility between grasses and, according to the simulation results reported here and in Ellis et al. (2011), this is to be expected at such a small difference in WSC content, and this is also likely the case for the $\mathrm{CH}_{4}$ emission estimates. In contrast, in experiment 1 of Lovett et al. (2006), 6 ryegrass varieties differing in WSC, CP, and NDF content were also compared for in vitro $\mathrm{CH}_{4}$ emissions. In these grasses, the largest difference between grasses in WSC was $33 \mathrm{~g} / \mathrm{kg}$ of DM at mainly the expense of NDF. The $72-\mathrm{h} \mathrm{CH}_{4}(\mathrm{~mL})$ and $\mathrm{CH}_{4}(\mathrm{~mL} / \mathrm{g}$ of digested $\mathrm{OM})$ decreased significantly with increased WSC, whereas no significant difference in OM digestibility was evident. The study of Lovett et al. (2006) provides no information about potential mechanisms behind the observed decrease, however.

The decrease in $\mathrm{CH}_{4}$ (g/kg of milk) simulated by the model is due to an increase in simulated milk yield (on average, $2.2 \mathrm{~kg} / \mathrm{d}$ ) for this scenario (Tables 2 and 3 ). Results show that an increase in milk yield associated with high-WSC grasses is most prominent when WSC was increased at the expense of NDF. When WSC increased at the expense of a 50:50 split of CP and NDF, a smaller increase in milk yield was observed, whereas a decrease in milk yield was observed when WSC increased at the expense of $\mathrm{CP}$ alone.

WSC Increases at the Expense of CP and $\boldsymbol{N D F}$. When WSC increased at the expense of a 50:50 split of CP and NDF (indicated by "CP and NDF scenario" from here on), simulation results are intermediary to the former 2 scenarios (Tables 2 and 3). Methane expressed as megajoules per day, percentage of GEI

Table 3. Simulated methane emissions and milk yield with grain feeding

\begin{tabular}{llcccc}
\hline $\begin{array}{l}\text { Simulation } \\
\text { identification }\end{array}$ & Description & $\begin{array}{c}\mathrm{CH}_{4} \\
(\mathrm{MJ} / \mathrm{d})\end{array}$ & $\begin{array}{c}\mathrm{CH}_{4} \\
\left(\% \text { of GEI }^{2}\right)\end{array}$ & $\begin{array}{c}\mathrm{CH}_{4}(\mathrm{~g} / \mathrm{kg} \\
\left.\text { of milk }^{3}\right)\end{array}$ & $\begin{array}{c}\text { Milk yield }^{3} \\
(\mathrm{~kg} / \mathrm{d})\end{array}$ \\
\hline 21 & $\mathrm{LN} / \mathrm{B} / \mathrm{G}$ & 19.7 & 6.04 & 13.9 & 25.5 \\
22 & $\mathrm{LN} / \mathrm{CP} / 20 / \mathrm{G}$ & 19.9 & 6.16 & 14.2 & 25.2 \\
23 & $\mathrm{LN} / \mathrm{CP} / 60 / \mathrm{G}$ & 20.4 & 6.40 & 14.9 & 24.6 \\
24 & $\mathrm{LN} / \mathrm{CP} / 90 / \mathrm{G}$ & 20.8 & 6.59 & 15.5 & 24.1 \\
25 & $\mathrm{LN} / \mathrm{NDF} / 20 / \mathrm{G}$ & 20.0 & 6.18 & 13.8 & 26.0 \\
26 & $\mathrm{LN} / \mathrm{NDF} / 60 / \mathrm{G}$ & 20.6 & 6.42 & 13.7 & 27.0 \\
27 & $\mathrm{LN} / \mathrm{NDF} / 90 / \mathrm{G}$ & 21.0 & 6.56 & 13.6 & 27.7 \\
28 & $\mathrm{LN} / \mathrm{CN} / 20 / \mathrm{G}$ & 20.0 & 6.17 & 14.0 & 25.7 \\
29 & $\mathrm{LN} / \mathrm{CN} / 60 / \mathrm{G}$ & 20.5 & 6.42 & 14.3 & 25.8 \\
30 & $\mathrm{LN} / \mathrm{CN} / 90 / \mathrm{G}$ & 20.9 & 6.59 & 14.5 & 26.0 \\
31 & $\mathrm{HN} / \mathrm{B} / \mathrm{G}$ & 19.2 & 5.70 & 12.8 & 26.9 \\
32 & $\mathrm{HN} / \mathrm{CP} / 20 / \mathrm{G}$ & 19.5 & 5.82 & 13.2 & 26.6 \\
33 & $\mathrm{HN} / \mathrm{CP} / 60 / \mathrm{G}$ & 20.0 & 6.07 & 13.9 & 25.9 \\
34 & $\mathrm{HN} / \mathrm{CP} / 90 / \mathrm{G}$ & 20.4 & 6.25 & 14.4 & 25.4 \\
35 & $\mathrm{HN} / \mathrm{NDF} / 20 / \mathrm{G}$ & 19.6 & 5.84 & 12.8 & 28.5 \\
36 & $\mathrm{HN} / \mathrm{NDF} / 60 / \mathrm{G}$ & 20.3 & 6.08 & 12.7 & 29.3 \\
37 & $\mathrm{HN} / \mathrm{NDF} / 90 / \mathrm{G}$ & 20.7 & 6.23 & 12.6 & 27.0 \\
38 & $\mathrm{HN} / \mathrm{CN} / 20 / \mathrm{G}$ & 19.6 & 5.84 & 13.0 & 27.2 \\
39 & $\mathrm{HN} / \mathrm{CN} / 60 / \mathrm{G}$ & 20.2 & 6.09 & 13.3 & 27.4 \\
40 & $\mathrm{HN} / \mathrm{CN} / 90 / \mathrm{G}$ & 20.6 & 6.26 & 13.5 & \\
\hline
\end{tabular}

${ }^{1} \mathrm{LN}$ represents low-N fertilized grass; $\mathrm{HN}$ represents high-N fertilized grass; basal water-soluble carbohydrate (WSC) levels are represented by B, and WSC increases at the expense of CP, NDF, or a 50:50 split of CP and NDF (CN); 20, 60, and 90 represent the level of grams per kilogram of DM trade that CP, NDF, or CN make with WSC as WSC of the grass increases; and G indicates the presence of grain $(2 \mathrm{~kg}$ of DM/d) in the diet. ${ }^{2} \mathrm{GEI}=$ gross energy intake.

${ }^{3}$ Milk yield is corrected to $3.5 \%$ milk fat and $3.2 \%$ milk protein. 
and grams per kilogram of milk all increased. In all simulations for this scenario, the digestibility of NDF and CP decreased slightly (see Ellis et al., 2011). Milk yield increased marginally (Tables 2 and 3), though not enough to cause $\mathrm{CH}_{4}$ ( $\mathrm{g} / \mathrm{kg}$ of milk) to decrease in these simulations.

When Lovett et al. (2004) examined 3 regrowth periods of grass, WSC increased by $26 \mathrm{~g} / \mathrm{kg}$ of DM at the expense of $\mathrm{CP}$ (NDF also increased slightly), and in vitro $\mathrm{CH}_{4}(\mathrm{~mL} / \mathrm{g}$ of $\mathrm{OM})$ decreased nonsignificantly, as well as $\mathrm{CH}_{4}(\mathrm{~mL} / \mathrm{g}$ of digested $\mathrm{OM})$. The highest $\mathrm{OM}$ digestibility was achieved for regrowth period 3 (lowest WSC content), followed by regrowth 1 (highest WSC content), followed by regrowth 2 (intermediate WSC content), indicating no clear trend. In experiment 2 of Lovett et al. (2006), the 2 grasses from experiment 1 representing lowest and highest WSC content (Yatsyn 1 and Kells, respectively) were compared again and a WSC $(\mathrm{g} / \mathrm{kg}$ of DM) difference of 14 , at the expense of a combination of $\mathrm{CP}$ and $\mathrm{NDF}$, resulted in a nonsignificant decrease in $72-\mathrm{h} \mathrm{CH}_{4}(\mathrm{~mL})$. Examination of harvest number (1 to 6 ), where WSC increased at the expense of a combination of $\mathrm{CP}$ and NDF, revealed no significant effect on $72 \mathrm{~h} \mathrm{CH}_{4}(\mathrm{~mL})$. Simulation results here indicate that changes in WSC content of 14 to $26 \mathrm{~g} / \mathrm{kg}$ of DM, as achieved by Lovett et al. (2004, 2006), may not be large enough to see any significant differences in $\mathrm{CH}_{4}$ results, and this is in line with the nonsignificant results observed by Lovett et al. (2004, 2006) for this scenario, even though Lovett observed numerical decreases.

Grams of WSC per Kilogram of DM Change. In the literature, $\mathrm{N}$ excretion levels between control and high-WSC treatments varied widely in terms of the significance and magnitude of the response (see Ellis et al., 2011). Some of this variation can be attributed to variation in the composition of the grass (WSC increasing at the expense of $\mathrm{CP}, \mathrm{NDF}$, or a mix of $\mathrm{CP}$ and NDF), but systematic evaluation by Ellis et al. (2011) revealed that the extent of change in plant composition strongly affected outcomes. Similarly, general patterns of response can be extracted from Tables 2 and 3 , but the magnitude of response depends strongly on the grams per kilogram of DM increase in WSC and the concurrent decrease in $\mathrm{CP}$ and NDF. At the lowest level of change $\left(20 \mathrm{~g} / \mathrm{kg}\right.$ of DM), simulated $\mathrm{CH}_{4}$ changes only minimally and considering the natural variation in $\mathrm{CH}_{4}$ emissions, may not become apparent from in vivo or even in vitro animal observations. Potentially more significant changes occur at the highest level of change $(90 \mathrm{~g} / \mathrm{kg}$ of DM).

Grain Feeding. In some high-WSC grass trials, the grass-based diets were supplemented with grain, and this scenario was also evaluated by Ellis et al. (2011) and in the present study. Not surprisingly, when $\mathrm{CH}_{4}$ was expressed as megajoules per day, feeding an additional $2 \mathrm{~kg}$ of grain per day resulted in an increase in average $\mathrm{CH}_{4}$ emissions (from 18.6 to $20.2 \mathrm{MJ} / \mathrm{d}$ ), due to the extra DMI and increase in digested DM (Table 2 versus Table 3 ). With no grain feeding, the average percent change in $\mathrm{CH}_{4}(\mathrm{MJ} / \mathrm{d})$ relative to the basal diets (simulations 1 and 11; across all simulation scenarios) was $+6.37 \%$, which decreased to $+4.23 \%$ change with grain feeding (relative to the basal diets, simulations 21 and 31, across all grain feeding scenarios). However, when $\mathrm{CH}_{4}$ was expressed as a percentage of GEI, the opposite was true. Methane decreased from an average of 6.46 to $6.18 \%$ of GEI, due to a higher passage rate of DMI, a related slight decrease in NDF digestibility (Ellis et al., 2011), and a slight increase in the molar proportion of propionic acid (data not shown). With no grain feeding, the average percentage change in $\mathrm{CH}_{4}$ (\% of GEI) relative to the basal diet was $+9.23 \%$, which decreased to a $+6.03 \%$ change with grain feeding. When $\mathrm{CH}_{4}$ was expressed as grams per kilogram of milk, the average value decreased from 15.4 to $13.7 \mathrm{~g} /$ $\mathrm{kg}$ of milk (Table 2 versus Table 3 ) due to an increase in simulated milk yield with additional grain feeding. The percent change in $\mathrm{CH}_{4}$ in $\mathrm{g} / \mathrm{kg}$ of milk (relative to the basal non-grain and grain simulations) decreased from $+3.50 \%$ for the non-grain simulations to $-0.61 \%$ for the grain-fed simulations, averaged across all grass compositions. Results show that grain feeding dilutes the effect of high-WSC grass feeding on the change in $\mathrm{CH}_{4}$ emissions. These results are as anticipated, and are related to the extra DMI with grain feeding and changes in digestibility (see also Ellis et al., 2011).

Nitrogen Fertilization. A basal versus high-N fertilization of grass scenario was evaluated, as it was also examined by Ellis et al. (2011) for its implication on $\mathrm{N}$ excretion. Results show that $\mathrm{CH}_{4}(\mathrm{MJ} / \mathrm{d})$ was slightly lower, on average, for the high- $\mathrm{N}$ fertilization scenarios compared with the low (19.6 vs. $19.2 \mathrm{MJ} / \mathrm{d}$ ), and the same was true of $\mathrm{CH}_{4}$ (\% of GEI; 6.51 vs. $6.13 \%)$ and $\mathrm{CH}_{4}(\mathrm{~g} / \mathrm{kg}$ of milk; 15.1 vs. 14.0; Tables 2 and 3). Relative to the basal diets (simulations 1 and 21 for low $\mathrm{N}$ and 11 and 31 for high $\mathrm{N}$ ), $\mathrm{CH}_{4}$ expressed in megajoules per day increased by $4.42 \%$ with the low- $\mathrm{N}$ diet and $4.78 \%$ with the high- $\mathrm{N}$ diet; $\mathrm{CH}_{4}$ expressed as percentage of GEI increased by 6.31 and $6.67 \%$, respectively; and $\mathrm{CH}_{4}$ expressed as grams per kilogram of milk increased by 3.12 and $3.63 \%$, respectively. Results indicate that the average $\mathrm{CH}_{4}$ is lower with high- $\mathrm{N}$ fertilization, and this result agrees with Murray et al. (2001) and Lovett et al. (2004), as well as with the whole-farm modeling results of Gregorini et al. (2010), who found decreased $\mathrm{CH}_{4}$ emission levels with increased $\mathrm{N}$ fertilization levels. 


\section{Selection of Units}

The simulations indicated differences in response (sign and magnitude) dependent on the units used to express $\mathrm{CH}_{4}$ emissions. Methane expressed relative to GEI is a way of accounting for differences in feeding level, and is the basic expression in the widely used Intergovernmental Panel on Climate Change (IPCC) Tier 2 method for inventory purposes. Results showed a significant trend for $\mathrm{CH}_{4}$ (\% of GEI and $\mathrm{MJ} / \mathrm{d}$ ) to increase with high-WSC grass feeding, depending on the specific grass composition. Variation in $\mathrm{CH}_{4}$ expressed per unit GEI observed in the present study, which is ignored in the IPCC Tier 2 approach, is qualitatively in line with the results of an independent evaluation of the IPCC Tier 2 approach (and other empirical approaches) to estimate $\mathrm{CH}_{4}$ production compared with actual observations (Ellis et al., 2010). Mechanistic models of fermentation processes such as used in the present study have been shown to have a higher prediction accuracy than the IPCC Tier 2 approach (Alemu et al., 2011). Of particular interest is expressing $\mathrm{CH}_{4}$ relative to the units of production, in this case milk yield $(\mathrm{kg} / \mathrm{d})$. The results showed that $\mathrm{CH}_{4}(\mathrm{~g} / \mathrm{kg}$ of milk) increased when WSC increased at the expense of $\mathrm{CP}$ or a mix of $\mathrm{CP}$ and NDF, but decreased when WSC increased at the expense of NDF, due to an increase in milk yield. Thus, depending on the units selected and the type of change in grass composition, the conclusions to be drawn may differ. Expressing $\mathrm{CH}_{4}$ as $\mathrm{MJ} / \mathrm{d}$ (or g/d) demonstrates that the ultimate impact of high-WSC grass feeding on the environment is an increased amount of $\mathrm{CH}_{4}$ per day. Methane expressed relative to intake (\% of GEI) also reveals that high-WSC grasses increase $\mathrm{CH}_{4}$ emissions. When $\mathrm{CH}_{4}$ is expressed relative to milk yield, however, results are variable. These results suggest that feeding high-WSC grass may only be beneficial for milking cows under conditions where milk yield is increased.

\section{DMI}

For the modeling exercises undertaken in the present study, DMI was held constant relative to the basal grass so that the effects of changes in grass composition could be isolated. However, reviewing the literature indicates that DMI may increase with high-WSC grass feeding, perhaps due to increased grass palatability. Gregorini et al. (2010) state that total DMI was 730 and $714 \mathrm{~kg}$ of DM/ha per year higher on the medium- and highWSC grasses relative to the baseline grass, although how they derived these values was not described. From a collection of published high-WSC grass studies, DMI change ranged from $-1.2 \mathrm{~kg}$ of $\mathrm{DM} / \mathrm{d}(-6.9 \%)$ to +2.6 $\mathrm{kg}$ of $\mathrm{DM} / \mathrm{d}(38.8 \%)$, with an average of $+0.18 \mathrm{~kg}$ of
DM/d (3.3\%; using the following studies: Miller et al. 2000, 2001a,b; Lee et al. 2002; Valk 2002; Tas et al. 2005, 2006a; Taweel et al. 2005a, 2006; Merry et al. 2006; Moorby et al. 2006) with changes in the WSC content of grass ranging from +11.0 to $+82.5 \mathrm{~g} / \mathrm{kg}$ of DM (average of $+38.6 \mathrm{~g} / \mathrm{kg}$ of DM). A meta-analysis of these data in PROC MIXED in SAS (SAS Institute, 2000), treating study as a random effect, of the relationship between grams per kilogram of DM change in the WSC content of grass ( $\triangle \mathrm{WSC}$ ) and percentage change in DMI (relative to the control grass) revealed the following significant relationship: percentage change in $\mathrm{DMI}=0.169( \pm 0.0614) \times \Delta \mathrm{WSC}(P=0.0128, \mathrm{BIC}$ $=146.1$ ). This equation would predict that at the $20 \mathrm{~g} /$ $\mathrm{kg}$ of DM exchange level, DMI would increase $3.4 \%$; at $60 \mathrm{~g} / \mathrm{kg}$ of DM exchange, it would increase by $10.1 \%$; and at $90 \mathrm{~g} / \mathrm{kg}$ of DM exchange, it would increase by $15.2 \%$, corresponding to a DMI of $16.5,17.6$, and 18.4 $\mathrm{kg} / \mathrm{d}$ for the low $\mathrm{N} / \mathrm{no}$ grain simulations performed here, respectively. When these elevated DMI values are run with the no-grain simulations described in Table 1 (for example), $\mathrm{CH}_{4}$ and milk yield predictions are as per Table 4. Milk yield increases across all simulations, due to the increased DMI. Methane $(\mathrm{MJ} / \mathrm{d}$ and \% of GEI) still increases; $\mathrm{CH}_{4}(\mathrm{MJ} / \mathrm{d})$ increases to a greater degree than the results in Table 2 (due to extra DMI), and $\mathrm{CH}_{4}$ (\% of GEI) to a lesser degree. The latter is explained by the higher fractional passage rate with increased DMI levels, thus decreasing substrate retention time and time for microbes to ferment substrate. Methane ( $\mathrm{g} / \mathrm{kg}$ of milk) still increased marginally when WSC increased at the expense of CP, but decreased when WSC increased at the expense of NDF or a combination of $\mathrm{CP}$ and NDF, due to the extra DMI and extra milk yield (Table 4).

Although $\mathrm{CH}_{4}$ emissions were not measured, Merry et al. (2006), with a $19 \%$ increase in DMI, observed a small nonsignificant decrease in acetate, and a small nonsignificant increase in propionate (\% of total VFA) with high-WSC grass silages, where the change in WSC content relative to the control grass was $35.9 \mathrm{~g} / \mathrm{kg}$ of DM, at the expense of mainly NDF and a small amount of CP. Stoichiometrically, assuming acetate and butyrate yield of $0.5 \mathrm{~mol}$ of $\mathrm{CH}_{4} / \mathrm{mol}$ of VFA and propionate yields of $-0.25 \mathrm{~mol}$ of $\mathrm{CH}_{4} / \mathrm{mol}$ of $\mathrm{VFA}, \mathrm{CH}_{4}$ (mmol of $\mathrm{CH}_{4} / \mathrm{mol}$ of VFA) would likely not differ for these diets, although the tendency was for it to decrease slightly (344 vs. 345, high-WSC and control grass, respectively). Tavendale et al. (2006) also reported VFA stoichiometry results (but again no $\mathrm{CH}_{4}$ results) for a high-WSC grass compared with an Italian and standard rye grass fed to nonlactating dairy cows; however, at a standardized DMI level ( $\sim 36 \mathrm{~kg}$ of DM grass allowance/cow per day). The WSC content of grass differed by $39.5 \mathrm{~g} / \mathrm{kg}$ 
Table 4. Simulated methane emissions and milk yield without grain feeding but with a sequential increase in $\mathrm{DMI}^{1}$ with increasing WSC content of grass

\begin{tabular}{|c|c|c|c|c|c|}
\hline $\begin{array}{l}\text { Simulation } \\
\text { identification }\end{array}$ & Description $^{2}$ & $\begin{array}{c}\mathrm{CH}_{4} \\
(\mathrm{MJ} / \mathrm{d})\end{array}$ & $\begin{array}{l}\mathrm{CH}_{4}(\% \\
\left.\text { of } \mathrm{GEI}^{3}\right)\end{array}$ & $\begin{array}{l}\mathrm{CH}_{4}(\mathrm{~g} / \mathrm{kg} \\
\left.\text { of milk }{ }^{4}\right)\end{array}$ & $\begin{array}{l}\text { Milk yield }^{4} \\
\quad(\mathrm{~kg} / \mathrm{d})\end{array}$ \\
\hline 41 & $\mathrm{LN} / \mathrm{B}$ & 18.1 & 6.28 & 15.5 & 20.9 \\
\hline 42 & $\mathrm{LN} / \mathrm{CP} / 20+\mathrm{DMI}$ & 18.8 & 6.38 & 15.6 & 21.6 \\
\hline 43 & $\mathrm{LN} / \mathrm{CP} / 60+\mathrm{DMI}$ & 20.2 & 6.55 & 15.7 & 23.1 \\
\hline 44 & LN/CP/90 + DMI & 21.3 & 6.70 & 15.7 & 24.3 \\
\hline 45 & $\mathrm{LN} / \mathrm{NDF} / 20+\mathrm{DMI}$ & 18.9 & 6.39 & 15.1 & 22.4 \\
\hline 46 & $\mathrm{LN} / \mathrm{NDF} / 60+\mathrm{DMI}$ & 20.5 & 6.55 & 14.3 & 25.6 \\
\hline 47 & $\mathrm{LN} / \mathrm{NDF} / 90+\mathrm{DMI}$ & 21.6 & 6.65 & 13.8 & 28.0 \\
\hline 48 & LN/CN/20 + DMI & 18.8 & 6.38 & 15.4 & 22.0 \\
\hline 49 & $\mathrm{LN} / \mathrm{CN} / 60+\mathrm{DMI}$ & 20.4 & 6.56 & 15.0 & 24.4 \\
\hline 50 & $\mathrm{LN} / \mathrm{CN} / 90+\mathrm{DMI}$ & 21.5 & 6.68 & 14.8 & 26.1 \\
\hline 51 & $\mathrm{HN} / \mathrm{B}$ & 17.6 & 5.88 & 14.3 & 22.2 \\
\hline 52 & $\mathrm{HN} / \mathrm{CP} / 20+\mathrm{DMI}$ & 18.4 & 5.97 & 14.3 & 23.1 \\
\hline 53 & $\mathrm{HN} / \mathrm{CP} / 60+\mathrm{DMI}$ & 19.9 & 6.16 & 14.5 & 24.6 \\
\hline 54 & $\mathrm{HN} / \mathrm{CP} / 90+\mathrm{DMI}$ & 20.9 & 6.29 & 14.7 & 25.6 \\
\hline 55 & $\mathrm{HN} / \mathrm{NDF} / 20+\mathrm{DMI}$ & 18.5 & 5.99 & 13.9 & 23.9 \\
\hline 56 & $\mathrm{HN} / \mathrm{NDF} / 60+\mathrm{DMI}$ & 20.1 & 6.16 & 13.2 & 27.3 \\
\hline 57 & $\mathrm{HN} / \mathrm{NDF} / 90+\mathrm{DMI}$ & 21.2 & 6.27 & 12.8 & 29.9 \\
\hline 58 & $\mathrm{HN} / \mathrm{CN} / 20$ + DMI & 18.4 & 5.98 & 14.1 & 23.5 \\
\hline 59 & $\mathrm{HN} / \mathrm{CN} / 60+\mathrm{DMI}$ & 20.0 & 6.18 & 13.9 & 26.0 \\
\hline 60 & $\mathrm{HN} / \mathrm{CN} / 90+\mathrm{DMI}$ & 21.2 & 6.31 & 13.7 & 27.7 \\
\hline
\end{tabular}

${ }^{1}$ The DMI of basal grass is according to Table 1 , and $+3.4 \%$ for $20 \mathrm{~g} / \mathrm{kg}$ of DM exchange, $+10.1 \%$ for $60 \mathrm{~g} / \mathrm{kg}$ of DM exchange, and $+15.2 \%$ for $90 \mathrm{~g} / \mathrm{kg}$ of DM exchange levels.

${ }^{2} \mathrm{LN}$ represents low-N fertilized grass; HN represents high-N fertilized grass; basal water-soluble carbohydrate (WSC) levels are represented by B, and WSC increases at the expense of CP, NDF, or a 50:50 split of CP and NDF (CN); 20, 60, and 90 represent the level of grams per kilogram of DM trade that CP, NDF, or CN make with WSC as WSC of the grass increases; + DMI indicates that additional DMI was simulated, according to footnote 1 .

${ }^{3} \mathrm{GEI}=$ gross energy intake.

${ }^{4}$ Milk yield is corrected to $3.5 \%$ milk fat and $3.2 \%$ milk protein.

of DM between the standard and high-WSC grasses, where WSC increased at the expense of a combination of CP and NDF. A similar stoichiometry calculation to the one above reveals a tendency for $\mathrm{CH}_{4}$ ( $\mathrm{mmol}$ of $\mathrm{CH}_{4} / \mathrm{mol}$ of VFA) to increase slightly (345 and 342, for high-WSC and standard grasses, respectively). These quick stoichiometry calculations do not, however, take into account concurrent changes in diet DM digestibility, which will also influence $\mathrm{CH}_{4}$ emission levels, and are accounted for in model simulations performed here.

In observed data, high levels of variability in DMI response are likely due to confounding changes in grass composition, digestibility, and grass quality in addition to the level of WSC increase achieved in the grass and perceived increases in palatability. When an increase in DMI is observed, on any diet, a shift toward less acetate and more propionate (\% of total VFA) is likely, in view of increased fractional passage rate, decreased fiber degradation, and reduced rumen $\mathrm{pH}$ (e.g., Robinson et al., 1986). Under these circumstances, $\mathrm{CH}_{4}$ (\% of GEI or $\mathrm{g} / \mathrm{kg}$ of DMI) may decrease. With a larger increase in WSC $(82.5 \mathrm{~g} / \mathrm{kg}$ of DM; again, at the expense of mainly NDF and a small amount of $\mathrm{CP}$ ) and an even larger increase in DMI (38.8\%), Lee et al. (2002) observed a significant decrease in rumen acetate (\% of total VFA) and a significant increase in propionate and butyrate (\% of total VFA) in steers. If a $38.8 \%$ increase in DMI is assumed in the current simulations, run with the simulations defined in Table $1, \mathrm{CH}_{4}(\mathrm{MJ} / \mathrm{d})$ increases more than in the Table 2 results (again, due to extra DMI), but $\mathrm{CH}_{4}$ (g/ $\mathrm{kg}$ of DM and $\mathrm{g} / \mathrm{kg}$ of milk) both decrease. Results are presented in Table 5 for only the $90 \mathrm{~g} / \mathrm{kg}$ of DM exchange level, where perhaps this $38.8 \%$ DMI increase may be possible. However, this DMI increase in steers with high-sugar grass is far more pronounced than studies in dairy cattle, where (using the relationship between DMI and WSC changes described previously) this increase was simulated to be $15.2 \%$.

Thus, in addition to the main determinants of $\mathrm{CH}_{4}$ emission level in the model-VFA stoichiometry, passage rate, $\mathrm{pH}$, and feed digestibility/degradation kinetics - differences in DMI will also affect potential $\mathrm{CH}_{4}$ emission results. Future studies examining $\mathrm{CH}_{4}$ emissions from high-WSC grass-fed cattle should consider whether consistent large increases in DMI can be achieved.

\section{Literature Data}

To simulate the degree of change in $\mathrm{CH}_{4}$ emissions that could be expected on real data, simulations were 
Table 5. Simulated methane emissions and milk yield without grain feeding but with a $38.8 \%$ increase in DMI for the nonbasal grass simulations

\begin{tabular}{|c|c|c|c|c|c|}
\hline $\begin{array}{l}\text { Simulation } \\
\text { identification }\end{array}$ & Description $^{1}$ & $\begin{array}{c}\mathrm{CH}_{4} \\
(\mathrm{MJ} / \mathrm{d})\end{array}$ & $\begin{array}{c}\mathrm{CH}_{4} \\
\left(\% \text { of } \mathrm{GEI}^{2}\right)\end{array}$ & $\begin{array}{c}\mathrm{CH}_{4}(\mathrm{~g} / \mathrm{kg} \\
\left.\text { of } \mathrm{milk}^{3}\right)\end{array}$ & $\begin{array}{l}\text { Milk yield }^{3} \\
\quad(\mathrm{~kg} / \mathrm{d})\end{array}$ \\
\hline 61 & $\mathrm{LN} / \mathrm{B}$ & 18.1 & 6.28 & 15.5 & 20.9 \\
\hline 62 & $\mathrm{LN} / \mathrm{CP} / 90+\mathrm{DMI}$ & 24.2 & 6.34 & 14.0 & 31.2 \\
\hline 63 & $\mathrm{LN} / \mathrm{NDF} / 90+\mathrm{DMI}$ & 24.7 & 6.33 & 12.5 & 35.6 \\
\hline 64 & $\mathrm{LN} / \mathrm{CN} / 90+\mathrm{DMI}$ & 24.5 & 6.35 & 13.3 & 33.1 \\
\hline 65 & $\mathrm{HN} / \mathrm{B}$ & 17.6 & 5.88 & 14.3 & 22.2 \\
\hline 66 & $\mathrm{HN} / \mathrm{CP} / 90+\mathrm{DMI}$ & 23.8 & 5.99 & 13.2 & 32.3 \\
\hline 67 & $\mathrm{HN} / \mathrm{NDF} / 90+\mathrm{DMI}$ & 24.2 & 5.98 & 11.5 & 37.9 \\
\hline 68 & $\mathrm{HN} / \mathrm{CN} / 90+\mathrm{DMI}$ & 24.1 & 6.01 & 12.4 & 35.1 \\
\hline
\end{tabular}

${ }^{1} \mathrm{LN}$ represents low-N fertilized grass; HN represents high-N fertilized grass; basal WSC levels are represented by B, and WSC increases at the expense of CP. NDF, or a 50:50 split of CP and NDF (CN); 90 represents the level of grams per kilogram of DM trade that CP, NDF, or CN make with WSC as WSC of the grass increases; + DMI indicates that an additional $38.8 \%$ DMI was simulated.

${ }^{2} \mathrm{GEI}=$ gross energy intake.

${ }^{3}$ Milk yield is corrected to $3.5 \%$ milk fat and $3.2 \%$ milk protein.

performed based on actual data from a literature database comprising experiments reported by Moorby et al. (2006), Tas et al. (2005, 2006a), Miller et al. (2001b), and Valk (2002). Description of this database, as well as evaluation of model-predicted $\mathrm{N}$ excretion, milk yield, and diet digestibility, were presented in Ellis et al. (2011). In line with the various simulation scenarios, the relationship between $\mathrm{CH}_{4}$ (expressed as $\mathrm{MJ} / \mathrm{d}, \%$ of GEI, and $\mathrm{g} / \mathrm{kg}$ of milk) and WSC content of the diets in this literature database revealed significant differences in the slope magnitude between studies, with at times, even directional differences (positive vs. negative) or a slope of zero (simulation results not shown). The observed change in WSC content (with a decrease in N fertilization level) in Valk (2002) ranged from -8 to +56 $\mathrm{g} / \mathrm{kg}$ of DM and, as WSC content increased $\mathrm{CH}_{4}$ (when expressed as \% of GEI or as $\mathrm{g} / \mathrm{kg}$ of milk), despite a decrease in NDF and $\mathrm{CP}$ digestibility, $\mathrm{CH}_{4}(\mathrm{MJ} / \mathrm{d})$ either increased slightly or stayed the same, depending on the year and season. In the study of Moorby et al. (2006), WSC increased from 161 to $241 \mathrm{~g} / \mathrm{kg}$ of DM, mainly at the expense of NDF in grass (from 563 to $480 \mathrm{~g} / \mathrm{kg}$ of DM, respectively). For the current study, simulated $\mathrm{CH}_{4}$ expressed as megajoules per day and percentage of GEI increased with the content of WSC in grass, but decreased when expressed as grams per kilogram of milk, due to an increase in observed DMI and simulated milk yield. In line with the scenario simulations, this again stresses the importance of possible changes in voluntary DMI upon changes in grass composition on $\mathrm{CH}_{4}$ emissions. The literature data of Miller et al. (2001b) and Tas et al. (2005, 2006a) contain examples of high-WSC grasses achieved when WSC increases at the expense of a (varying) combination of $\mathrm{CP}$ and NDF. Indeed, simulated $\mathrm{CH}_{4}$ increased (MJ/d and \% of GEI) for the Miller et al. (2001b) data (WSC increase from
126 to $165 \mathrm{~g} / \mathrm{kg}$ of DM) with an associated increase in NDF and CP digestibility. Milk yield increased enough to have $\mathrm{CH}_{4}$ (g/kg of milk) decrease slightly. The Tas et al. $(2005,2006 a)$ data are more variable. Results on $\mathrm{CH}_{4}$ emissions within Latin square depended on the grams per kilogram of DM difference in WSC, CP, and NDF, which tended to be on the low side $(15-45 \mathrm{~g} / \mathrm{kg}$ of $\mathrm{DM})$. In general, $\mathrm{CH}_{4}$ hardly changed when expressed as megajoules per day and grams per kilogram of milk, but increased at the highest WSC level when expressed as percentage of GEI. It is likely that the low levels of response in these data are the result of small and inconsistent grams per kilogram of DM exchanges between the chemical fractions in dietary DM. Another major difference between the Moorby et al. (2006) and Miller et al. (2001b) experiments, compared with the Tas et al. $(2005,2006 \mathrm{a})$ and Valk (2002) experiments, is that the DMI tended to increase far more with high-WSC grasses in the former than the latter. As a consequence, milk yield differences between low- and high-WSC grasses were more pronounced in Moorby et al. (2006) and Miller et al. (2001b). This resulted in a more pronounced decrease in $\mathrm{CH}_{4}$ expressed in grams per kilogram of milk, because higher milk production levels are generally associated with decreased $\mathrm{CH}_{4}$ emissions as non-production energy expenditure (maintenance) is a smaller part of total energy expenditure at high milkproduction levels. These literature simulations give an indication of the type and range of $\mathrm{CH}_{4}$ responses that may be observed in practice.

\section{Integrative Effects}

Figure 3 illustrates the relationship between N excretion [expressed as urine $\mathrm{N}$ (\% of $\mathrm{N}$ intake) or as the $\mathrm{N}$ utilization ratio; Ellis et al., 2011] and $\mathrm{CH}_{4}$ emissions 
(expressed as $\mathrm{g} / \mathrm{kg}$ of milk or \% of GEI) for the simulation database when DMI was held constant. In general, these plots illustrate that as the ingested grass becomes more beneficial in terms of $\mathrm{N}$ excretion, it becomes more problematic for $\mathrm{CH}_{4}$ emission. Gregorini et al. (2010) showed similar results based on a whole-farm simulation. However, examination of results presented here reveal that the pattern is not inclusive of all grass composition simulations. When $\mathrm{CH}_{4}$ (\% of GEI) is plotted against the $\mathrm{N}$ utilization ratio of the diet (milk $\mathrm{N}$ /feed $\mathrm{N}$ ), regardless of the simulated condition, $\mathrm{N}$ utilization improves and $\mathrm{CH}_{4}$ emissions increase. However, with the use of different units, different patterns emerge. When $\mathrm{CH}_{4}$ (\% of GEI) is plotted against urine $\mathrm{N}$ (\% of $\mathrm{N}$ intake), in general, $\mathrm{CH}_{4}$ increases as urine $\mathrm{N}$ decreases. However, for simulations where WSC increased at the expense of NDF, no change in urine $\mathrm{N}$ is evident, whereas $\mathrm{CH}_{4}$ tends to increase. When $\mathrm{CH}_{4}$ is expressed as grams per kilogram of milk instead, minimal to no change in urine $\mathrm{N}$ is associated with minimal to no change in $\mathrm{CH}_{4}$. On the other hand, for simulations where WSC increased at the expense of NDF, the relationships between $\mathrm{CH}_{4}$ expressed in grams per kilogram of milk and $\mathrm{N}$ utilization ratio is small and negative, whereas it is positive with the other simulated scenarios. Therefore, the relationship largely depends on the units used, and whether a decrease in $\mathrm{CH}_{4}$ or $\mathrm{N}$ relative to intake is desired, or a decrease in $\mathrm{CH}_{4}$ or $\mathrm{N}$ relative to unit of production.

Of interest is how to compare or equate the changes in on-farm $\mathrm{N}$ emissions with the changes in simulated $\mathrm{CH}_{4}$ emissions. One such way is to convert eructated $\mathrm{CH}_{4}$ and the nitrous oxide $\left(\mathrm{N}_{2} \mathrm{O}\right)$ produced from excreted $\mathrm{N}$ (on average, $2 \%$ of excreted $\mathrm{N}$ is converted into $\mathrm{N}_{2} \mathrm{O}$; IPCC Tier II guidelines; Jun et al., 2001) into $\mathrm{CO}_{2}$ equivalents, and examine emissions from the whole animal or the whole farm (Beukes et al., 2010). Methane has a global warming potential roughly 25 times as potent as $\mathrm{CO}_{2}$ and $\mathrm{N}_{2} \mathrm{O}$ has a global warming potential roughly 298 times as potent as $\mathrm{CO}_{2}$. How-
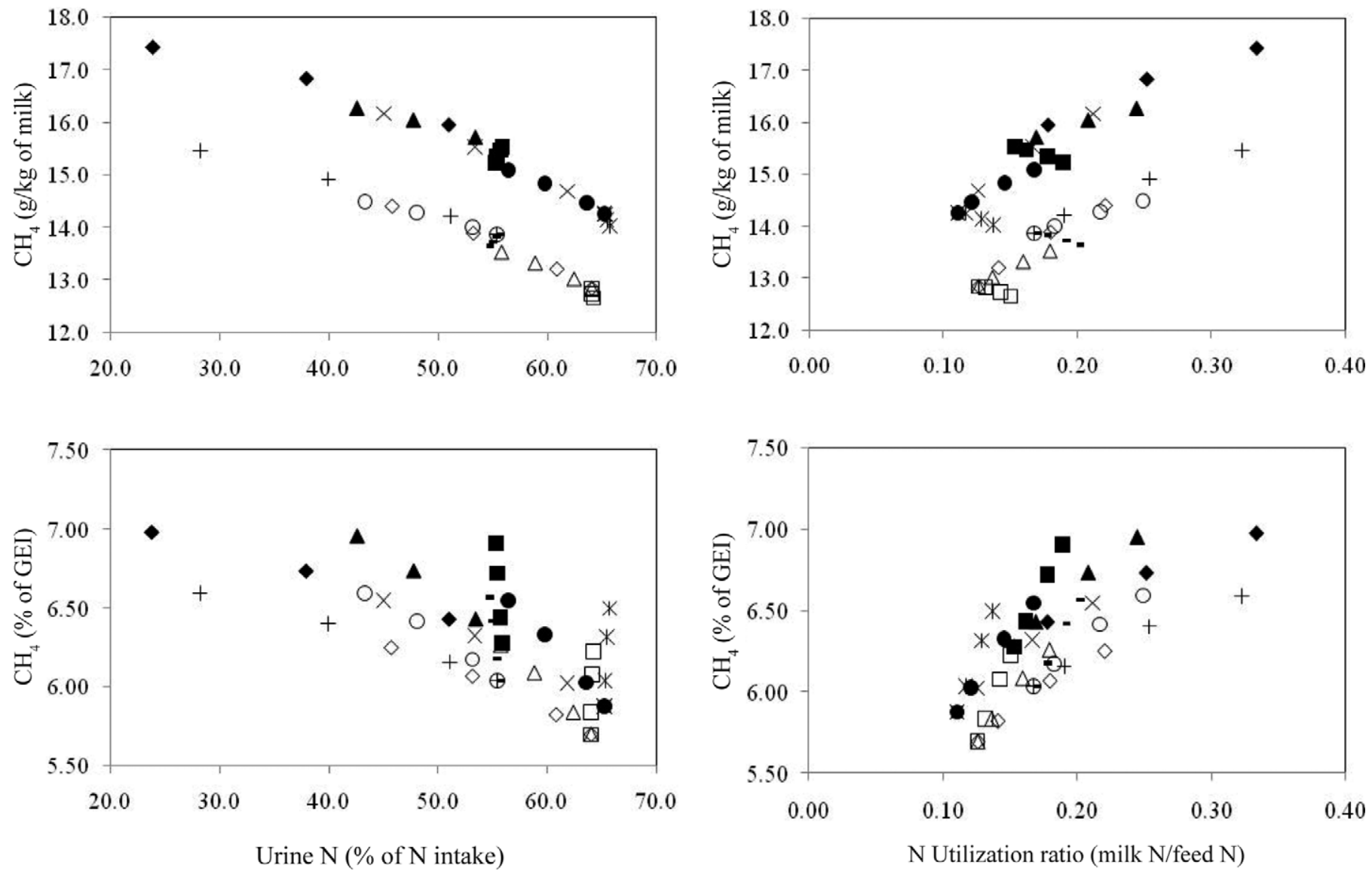

Figure 3. Simulated $\mathrm{CH}_{4}$ expressed as grams per kilogram of fat- and protein-corrected milk (top) or as percentage of gross energy intake (GEI ; bottom) versus the simulated urine $\mathrm{N}$ expressed as percentage of $\mathrm{N}$ intake (graphs at left-hand side) and $\mathrm{N}$ utilization ratio of the diet expressed as milk N/feed N (graphs at right-hand side). - simulations 1-4; simulations 5-7; $\boldsymbol{\Delta}$ simulations 8-10; $\times$ simulations 11-14; $\times($ with vertical line) simulations $15-17$; simulations $18-20 ;+$ simulations $21-24 ;-$ simulations $25-27 ; \bigcirc$ simulations $28-30 ; \diamond$ simulations $31-34 ; \square$ simulations $35-37 ; \Delta$ simulations $38-40$, all according to Table 1. 
ever, quick conversions here to $\mathrm{CO}_{2}$ equivalents exclude $\mathrm{CH}_{4}$ or ammonia produced from manure, and cannot equate the effect of $\mathrm{N}$ on, for example, surface water or soil contamination and indirect emissions. To get a more realistic evaluation of management strategies in terms of the net effect of emissions to the environment, whole-farm evaluations that are sensitive to changes in dietary strategies, animal productivity, and nutrient excretion are required (such as Beukes et al., 2010).

\section{High-WSC Grass}

Extensive variation in published studies suggests no clear or standard definition of what a high-WSC grass is. How elevated WSC content is achieved has been illustrated in the present study as well as by Ellis et al. (2011) to have a major influence on the pattern of $\mathrm{N}$ and enteric $\mathrm{CH}_{4}$ emissions. In addition, the actual grams per kilogram of DM level of WSC elevation varies extensively between studies. Simulation results in the present study suggest that increases of more than 20 to $40 \mathrm{~g} / \mathrm{kg}$ of DM may be required to be able to find significant results in vivo.

We also propose that the type of WSC present in grass needs further examination. Differences in the type of WSC present in the diet can yield differences in the VFA profile of the rumen (Sutton, 1968; Czerkawski and Breckenridge, 1969; Sutton 1969) and affect $\mathrm{CH}_{4}$ emissions. Hindrichsen et al. (2005) reported significantly higher $\mathrm{CH}_{4}$ emissions (g/d) with increased sugar levels, but found no difference in enteric $\mathrm{CH}_{4}$ emissions between diets with carbohydrate sources rich in artichoke tubers (high in fructans, $186 \mathrm{~g} / \mathrm{kg}$ of DM) versus molasses (high in sugar, $139 \mathrm{~g} / \mathrm{kg}$ of DM), but starch, cellulose, and hemicellulose contents also simultaneously differed. It should be investigated how variations in grass sugar composition affect $\mathrm{N}$ excretion, DMI, or milk yield. The Valk (2002) data achieved high- versus low-WSC diets by altering the $\mathrm{N}$ fertilization level. The Moorby et al. (2006) UK data accentuated the difference between high- and low-WSC grasses by cutting the grasses at different times during the day. How and if these different strategies alter the sugar composition of the grass is worth examining. Variation between UK, Dutch, and New Zealand data has also been suggested to be due to environmental interactions such as rainfall levels and local temperature (Edwards et al., 2007). Certainly, it seems that the partitioning of sugars in perennial ryegrass is affected by rainfall and drought (Thomas and James, 1999), which could be part of the environmental interaction, as well as other factors such as latitude and day length. Seasonal changes also affect the composition of sugars in ryegrass (Gonzalez et al., 1990). Although the Miller et al. (2001b) trial observed an increase in grass DM digestibility with high-WSC grass, other trials did not. Whether DM and NDF digestibility actually increase in these grasses is likely the result of a combination of cultivar effect, DMI, type of NDF, and effects of rumen conditions on VFA profile, microbial growth and $\mathrm{N}$ digestion, and should be examined experimentally in more detail. Although the current study and the work of Ellis et al. (2011) propose to explain some of the variation in observed results, WSC composition and forage digestibility are additional areas requiring investigation.

\section{CONCLUSIONS}

With an increase in the WSC content of grass, simulated $\mathrm{CH}_{4}$ emission tended to increase when $\mathrm{CH}_{4}$ was expressed as megajoules per day or percentage of GEI, but results were more variable when $\mathrm{CH}_{4}$ was expressed as grams per kilogram of milk. Thus, the units chosen to express $\mathrm{CH}_{4}$ emission is found to be very important with respect to quantifying the size and sign of the effect of grass type on enteric $\mathrm{CH}_{4}$ emission. The largest increases in $\mathrm{CH}_{4}$ emissions were simulated when WSC increased at the expense of $\mathrm{CP}$ in the diet. Potential exists for $\mathrm{CH}_{4}$ (\% of GEI or $\mathrm{g} / \mathrm{kg}$ of milk but not MJ/d) to decrease if the DMI associated with the high-WSC grass is elevated enough. The present simulation results indicate that the $\mathrm{N}$ mitigation strategy of increasing the WSC content of grass can increase $\mathrm{CH}_{4}$ emissions. This study illustrates one of the roles for modeling in dairy science - that of integrating and synthesizing a group of related but not necessarily conclusive research experiments and examining the underlying principles.

\section{ACKNOWLEDGMENTS}

Funding for this project was provided primarily by the Canada Research Chairs Program and the Natural Sciences and Engineering Research Council's Strategic Grants Program. Dairy Farmers of Canada (Ottawa, ON, Canada) is also thanked for financial support. J. L. Ellis gratefully received a Wageningen Institute of Animal Sciences (WIAS) research fellowship, as well as funding from the Animal Sciences Group, Wageningen University and Research Centre (UR), in Lelystad, the Netherlands.

\section{REFERENCES}

Alemu, A. W., J. Dijkstra, A. Bannink, J. France, and E. Kebreab. 2011. Rumen stoichiometric models and their contribution and challenges in predicting enteric methane production. Anim. Feed Sci. Technol. 166-167:761-778.

Baldwin, R. L., J. France, and D. E. Beever. 1987a. Metabolism of the lactating cow III. Properties of mechanistic models suitable for evaluation of energetic relationships and factors involved in the partition of nutrients. J. Dairy Res. 54:133-145. 
Baldwin, R. L., J. France, and M. Gill. 1987b. Metabolism of the lactating cow I. Animal elements of a mechanistic model. J. Dairy Res. 54:77-105.

Baldwin, R. L., J. H. M. Thornley, and D. E. Beever. 1987c. Metabolism of the lactating cow. II. Digestive elements of a mechanistic model. J. Dairy Res. 54:107-131.

Bannink, A., J. France, S. López, W. J. J. Gerrits, E. Kebreab, S. Tamminga, and J. Dijkstra. 2008. Modelling the implications of feeding strategy on rumen fermentation and functioning of the rumen wall. Anim. Feed Sci. Technol. 143:3-26.

Bannink, A., M. C. J. Smits, E. Kebreab, J. A. N. Mills, J. L. Ellis, A. Klop, J. France, and J. Dijkstra. 2010. Simulating the effects of grassland management and grass ensiling on methane emission from lactating cows. J. Agric. Sci. 148:55-72.

Beauchemin, K. A., T. A. McAllister, and S. M. McGinn. 2009. Dietary mitigation of enteric methane from cattle. CAB Reviews: Perspectives in Agriculture, Veterinary Science, Nutrition and Natural Resources 4:1-18.

Benchaar, C., J. Rivest, C. Pomar, and J. Chiquette. 1998. Prediction of methane production from dairy cows using existing mechanistic models and regression equations. J. Anim. Sci. 76:617-627.

Bernard, J. K. 1997. Milk production and composition responses to the source of protein supplements in diets containing wheat middlings. J. Dairy Sci. 80:938-942.

Beukes, P. C., P. Gregorini, A. J. Romera, G. Levy, and G. C. Waghorn. 2010. Improving production efficiency as a strategy to mitigate greenhouse gas emissions on pastoral dairy farms in New Zealand. Agric. Ecosyst. Environ. 136:358-365.

Cosgrove, G. P., J. L. Burke, A. F. Death, M. J. Hickey, D. Pacheco, K. Fraser, and G. A. Lane. 2007. Ryegrass with increased water soluble carbohydrate: Evaluating the potential for grazing dairy cows in New Zealand. Proc. New Zealand Grassl. Assoc. 69:179 185.

CVB (Centraal Veevoederbureau). 2007. CVB Table Ruminants 2007, series no. 32. CVB, The Hague, the Netherlands.

Czerkawski, J. W., and G. Breckenridge. 1969. Fermentation of various soluble carbohydrates by rumen micro-organisms with particular reference to methane production. Br. J. Nutr. 23:925-937.

Dijkstra, J., J. France, A. G. Assis, H. D. St. C. Neal, O. F. Campos, and L. J. M. Aroeira. 1996. Simulation of digestion in cattle fed sugarcane: Prediction of nutrient supply for milk production with locally available supplements. J. Agric. Sci. 127:247-260.

Dijkstra, J., E. Kebreab, A. Bannink, L. A. Crompton, S. Lopez, P. A. Abrahamse, P. Chilibroste, J. A. N. Mills, and J. France. 2008. Comparison of energy evaluation systems and a mechanistic model for milk production by dairy cattle offered fresh grass-based diets. Anim. Feed Sci. Technol. 143:203-219.

Dijkstra, J., E. Kebreab, J. A. N. Mills, W. F. Pellikaan, S. López, A. Bannink, and J. France. 2007. Predicting the profile of nutrients available for absorption: From nutrient requirement to animal response and environmental impact. Animal 1:99-111.

Dijkstra, J., D. St. C. Neal, D. E. Beever, and J. France. 1992. Simulation of nutrient digestion, absorption and outflow in the rumen: Model description. J. Nutr. 122:2239-2256.

Edwards, G. R., A. J. Parsons, and S. Rasmussen. 2007. High sugar ryegrasses for dairy systems. Pages 307-334 in Meeting the Challenges for Pasture-Based Dairying. Proc. Australasian Dairy Science Symposium. D. F. Chapman, D. A. Clark, K. L. MacMillan, and D. P. Nation, ed. University of Melbourne, National Dairy Alliance, Melbourne, Australia.

Ellis, J. L., A. Bannink, J. Dijkstra, A. J. Parsons, S. E. Rasmussen, G. R. Edwards, E. Kebreab, and J. France. 2009. A modelling approach to evaluate the feeding of high sugar grasses to cattle: Nitrogen and methane. Can. J. Anim. Sci. 89:532-533. (Abstr.)

Ellis, J. L., A. Bannink, J. France, E. Kebreab, and J. Dijkstra. 2010. Evaluation of enteric methane prediction equations for dairy cows used in whole farm models. Glob. Change Biol. 16:3246-3256.

Ellis, J. L., J. Dijkstra, A. Bannink, A. J. Parsons, S. Rasmussen, G. R. Edwards, E. Kebreab, and J. France. 2011. The effect of high sugar grass on predicted nitrogen emission and milk yield simulated within a dynamic model. J. Dairy Sci. 94:3105-3118.
Ellis, J. L., J. Dijkstra, E. Kebreab, A. Bannink, N. E. Odongo, B. W. McBride, and J. France. 2008. Aspects of rumen microbiology central to mechanistic modelling of methane production in cattle. J. Agric. Sci. 146:213-233.

Gonzalez, B., J. Boucaud, J. Salette, and J. Langlois. 1990. Fructan and cyroprotection in ryegrass (Lolium perenne L.). New Phytol. 115:319-323.

Gregorini, P., P. C. Beukes, R. H. Bryant, and A. J. Romera. 2010. A brief overview and simulation of the effects of some feeding strategies on nitrogen excretion and enteric methane emission from grazing dairy cows. Pages $29-43$ in Proc. 4th Aust. Dairy Sci. Symp., Lincoln University, New Zealand. Caxton Press, Christchurch, New Zealand.

Hindrichsen, I. K., H.-R. Wettstein, A. Machmüller, B. Jörg, and M. Kreuzer. 2005. Effect of the carbohydrate composition of feed concentrates on methane emission from dairy cows and their slurry. Environ. Monit. Assess. 107:329-350.

Jun, P., M. Gibbs, and K. Gaffney. 2001. $\mathrm{CH}_{4}$ and $\mathrm{N}_{2} \mathrm{O}$ emissions from livestock manure. IPCC Good Practices Guidance and Uncertainty Management in National Greenhouse Gas Inventories. Accessed Sept. 27, 2010. http://www.ipcc-nggip.iges.or.jp/public/ $\mathrm{gp} / \mathrm{bgp} / 4 \_2$ CH4 4 and_N2O_Livestock_Manure.pdf.

Lee, M. R. F., L. J. Harris, J. M. Moorby, M. O. Humphreys, M. K. Theodorou, J. C. MacRae, and N. D. Scollan. 2002. Rumen metabolism and nitrogen flow to the small intestine in steers offered Lolium perenne containing different levels of water-soluble carbohydrate. Anim. Sci. 74:587-596.

Lovett, D. K., A. Bortolozzo, P. Conaghan, P. O'Kiely, and F. P. O'Mara. 2004. In vitro total and methane gas production as influenced by rate of nitrogen application, season of harvest and perennial ryegrass cultivar. Grass Forage Sci. 59:227-232.

Lovett, D. K., D. McGilloway, A. Bortolozzo, M. Hawkins, J. Callan, B. Flynn, and F. P. O'Mara. 2006. In vitro fermentation patterns and methane production as influenced by cultivar and season of harvest of Lolium perenne L. Grass Forage Sci. 61:9-21.

Merry, R. J., M. R. F. Lee, D. R. Davies, R. J. Dewhurst, J. M. Moorby, N. D. Scollan, and M. K. Theodorou. 2006. Effects of high-sugar ryegrass silage and mixtures with red clover silage on ruminant digestion. 1 . In vitro and in vivo studies of nitrogen utilization. J. Anim. Sci. 84:3049-3060.

Miller, L. A., D. H. Baker, M. K. Theodorou, J. C. MacRae, M. O. Humphreys, N. D. Scollan, and J. M. Moorby. 2001a. Efficiency of nitrogen use in dairy cows grazing ryegrass with different water soluble carbohydrate concentrations. Pages 377-378 in Grassland Ecosystems: An outlook into the 21st Century. Proc. 19th Int. Grasslands Congress. J. A. Gomide, W. R. S. Mattos and S. Carneiro da Silva, ed. Sao Paulo, Brazil. Int. Grassl. Congress, Piracicaba, Brazil.

Miller, L. A., J. M. Moorby, D. R. Davies, M. O. Humphreys, N. D. Scollan, J. C. MacRae, and M. K. Theodorou. 2001b. Increased concentration of water-soluble carbohydrate in perennial ryegrass (Lolium perenne L.): Milk production from late-lactation dairy cows. Grass Forage Sci. 56:383-394.

Miller, L. A., M. K. Theodorou, J. C. MacRae, R. T. Evans, M. O. Humphreys, N. D. Scollan, and J. M. Moorby. 2000. Efficiency of nitrogen use by dairy cows offered perennial ryegrass with high water soluble carbohydrate concentrations. Pages 37-38 in Proc. 6th Res. Conf. Br. Grassl. Soc., Aberdeen, UK. Br. Grassl. Soc., Kenilworth, UK.

Mills, J. A. N., J. Dijkstra, A. Bannink, S. B. Cammell, E. Kebreab, and J. France. 2001. A mechanistic model of whole-tract digestion and methanogenesis in the lactating dairy cow: Model development, evaluation, and application. J. Anim. Sci. 79:1584-1597.

Moorby, J. M., R. T. Evans, N. D. Scollan, J. C. MacRae, and M. K. Theodorou. 2006. Increased concentration of water-soluble carbohydrate in perennial ryegrass (Lolium perenne L.). Evaluation in dairy cows in early lactation. Grass Forage Sci. 61:52-59.

Murray, P. J., E. Gill, S. L. Balsdon, and S. C. Jarvis. 2001. A comparison of methane emissions from sheep grazing pastures with differing management intensities. Nutr. Cycl. Agroecosyst. 60:93-97. 
Reijs, J. W. 2007. Improving slurry by diet adjustments. A novelty to reduce $\mathrm{N}$ losses from grassland based dairy farms. PhD Thesis. Wageningen University, Wageningen, the Netherlands.

Robinson, P. H., S. Tamminga, and A. M. van Vuuren. 1986. Influence of declining level of feed intake and varying the proportion of starch in the concentrate on rumen fermentation in dairy cows. Livest. Prod. Sci. 15:173-189.

SAS Institute. 2000. SAS User's Guide: Statistics. SAS Inst. Inc., Cary, NC.

Sauvant, D., J.-M. Perez, and G. Tran, ed. 2004. Tables of Composition and Nutritional Value of Feed Materials. Wageningen Academic Publishers, Wageningen, the Netherlands/Institut National de la Recherche Agronomique (INRA), Paris, France.

Seo, S., L. O. Tedeschi, C. Lanzas, C. G. Schwab, and D. G. Fox. 2006. Development and evaluation of empirical equations to predict feed passage rate in cattle. Anim. Feed Sci. Technol. 128:67-83.

Sutton, J. D. 1968. The fermentation of soluble carbohydrates in rumen contents of cows fed diets containing a large proportion of hay. Br. J. Nutr. 22:689-712.

Sutton, J. D. 1969. The fermentation of soluble carbohydrates in rumen contents of cows given diets containing a large proportion of flaked maize. Br. J. Nutr. 23:567-583.

Tas, B. M., H. Z. Taweel, H. J. Smit, A. Elgersma, J. Dijkstra, and S. Tamminga. 2005. Effects of perennial ryegrass cultivars on intake, digestibility and milk yield in dairy cows. J. Dairy Sci. $88: 3240-3248$.

Tas, B. M., H. Z. Taweel, H. J. Smit, A. Elgersma, J. Dijkstra, and S. Tamminga. 2006a. Utilisation of $\mathrm{N}$ in perennial ryegrass cultivars by stall-fed lactating dairy cows. Livest. Sci. 100:159-168.

Tas, B. M., H. Z. Taweel, H. J. Smit, A. Elgersma, J. Dijkstra, and S. Tamminga. 2006b. Effects of perennial ryegrass cultivars on milk yield and nitrogen utilization in grazing dairy cows. J. Dairy Sci. 89:3494-3500.
Tavendale, M. H., D. Pacheco, G. A. Lane, K. Fraser, A. F. Death, J. L. Burke, M. J. Hickey, and G. P. Cosgrove. 2006. The effects of ryegrass varieties differing in soluble sugar content on the rumen fermentation of amino acids and consequences for milk flavour chemistry. Proc. N.Z. Grassl. Assoc. 68:261-265.

Taweel, H. Z., B. M. Tas, H. J. Smit, A. Elgersma, J. Dijkstra, and S. Tamminga. 2005a. Effects of feeding perennial ryegrass with an elevated concentration of water-soluble carbohydrate on intake, rumen function and performance of dairy cows. Anim. Feed Sci. Technol. 121:243-256.

Taweel, H. Z., B. M. Tas, H. J. Smit, A. Elgersma, J. Dijkstra, and S. Tamminga. 2005b. Improving the quality of perennial ryegrass (Lolium perenne L.) for dairy cows by selecting for fast clearing and/or degradable neutral detergent fiber. Livest. Prod. Sci. $96: 239-248$.

Taweel, H. Z., B. M. Tas, H. J. Smit, A. Elgersma, J. Dijkstra, and S. Tamminga. 2006. Grazing behaviour, intake, rumen function and milk production of dairy cows offered Lolium perenne containing different levels of water-soluble carbohydrates. Livest. Sci. 102:33-41.

Thomas, H., and A. R. James. 1999. Partitioning of sugars in Lolium perenne (perennial ryegrass) during drought and on rewatering. New Phytol. 142:295-305.

Valk, H. 2002. Nitrogen and phosphorus supply of dairy cows. PhD Thesis. Wageningen University, Wageningen, the Netherlands.

Valk, H., I. E. Kappers, and S. Tamminga. 1996. In sacco degradation characteristics of organic matter, neutral detergent fibre and crude protein of fresh grass fertilized with different amounts of nitrogen. Anim. Feed Sci. Technol. 63:63-87.

Valk, H., I. E. Leusink-Kappers, and A. M. van Vuuren. 2000. Effect of reducing nitrogen fertilizer on grassland on grass intake, digestibility and milk production of dairy cows. Livest. Prod. Sci. $63: 27-38$. 